\title{
ALTERNATIF PENANGANAN BENCANA BANJIR: STUDI KASUS SITUS CANDI RONGGENG, PAMARICAN, CIAMIS
}

\author{
Flood Disaster Alternative Treatment: \\ Case Study on Candi Ronggeng Site, Pamarican, Ciamis
}

\author{
Endang Widyastuti \\ Balai Arkeologi Jawa Barat \\ Jalan Raya Cinunuk Km. 17 Cileunyi, Bandung \\ E-mail: endangwidyastuti6@gmail.com
}

\begin{abstract}
Candi Ronggeng Site administratively located in Sukajaya Village, sub-district of Pamarican, District of Ciamis, placed in the coordinate $7^{\circ} 25^{\prime} 46.92^{\prime \prime} L S$ and 108 29'37.17"BT. The site's morphology is an undulated plains on a valley near Ci Seel, a creek of Ci Tanduy which has the upstream on Cakrabuana Mountain in Tasikmalaya District, and boils down to Segara Anakan in Central Java Province. Ci Seel flows on the northern side of the site, with a meander pattern and creeks turns from the west side to the east side. This land is often flooded so the sedimentation is high. The object in the form of temple stone that was visible, now buried in the sediment. Based on the excavation report from previous years, the biggest flood ever happen was on 1937,1943, 1962, 1973, and even more often since Gunung Putri dam was built around 1970. The trail of flood sediment is visible up to a thickness of $140 \mathrm{~cm}$ to $200 \mathrm{~cm}$ from the original soil, which is brownish black and has a sand-clay texture. This article aimed to propose an alternative treatment for flood disaster, so that this temple could be saved as one of Ciamis's assets. The discussion that done such as observing the temple and it's environment condition, sedimentation of flood overflow data, and rainfall. Furthermore, this article proposes some steps that should be taken so that the Candi Ronggeng site is protected from flooding.
\end{abstract}

Keyword: Candi Ronggeng, flood, Ci Seel, Gunung Putri Dam, Ciamis

\begin{abstract}
Abstrak
Situs Candi Ronggeng secara administratif terletak di Desa Sukajaya, Kecamatan Pamarican, Kabupaten Ciamis, berada pada koordinat $7^{\circ} 25^{\prime} 46.92$ 'LS dan $108^{\circ} 29^{\prime} 37.17^{\prime \prime B T}$. Morfologi situs berupa dataran bergelombang di lembah Ci Seel anak sungai Ci Tanduy yang berhulu di Gunung Cakrabuana di Kabupaten Tasikmalaya, dan bermuara di Segara Anakan Provinsi Jawa Tengah. Ci Seel mengalir di sebelah utara situs, dengan pola aliran meander dengan anak-anak sungai, berkelok-kelok dari arah barat ke timur. Lahan ini sering tergenang banjir sehingga terjadi sedimentasi yang sangat tinggi. Objek berupa batu candi yang semula masih terlihat, sekarang terkubur endapan tanah. Berdasarkan laporan penggalian pada tahun-tahun sebelumnya, banjir besar pernah terjadi pada tahun 1937, 1943, 1962, 1973 dan lebih sering lagi sejak dibangunnya bendungan Gunung Putri pada sekitar tahun 1970-an. Jejak endapan banjir tersebut terlihat hingga mencapai ketebalan $140 \mathrm{~cm}$ sampai dengan $200 \mathrm{~cm}$ dari tanah aslinya yang berwarna hitam kecoklatan dan bertekstur pasir-lempungan. Paparan ini bermaksud mengajukan alternatif untuk menangani banjir, sehingga candi ini dapat diselamatkan sebagai salah satu aset daerah Ciamis. Pembahasan dilakukan di antaranya dengan melihat kondisi candi dan lingkungannya, data pengendapan limpah banjir, dan curah hujan. Selanjutnya diajukan beberapa langkah yang sebaiknya dilakukan sehingga situs Candi Ronggeng terhindar dari banjir.
\end{abstract}

Kata Kunci: Candi Ronggeng, banjir, Ci Seel, bendungan Gunung Putri, Ciamis 


\section{PENDAHULUAN}

Kabupaten Ciamis merupakan salah satu wilayah di Jawa Barat yang diketahui menyimpan potensi arkeologi cukup besar. Potensi arkeologi wilayah Ciamis berasal dari rentang waktu yang cukup panjang, sejak masa prasejarah hingga masa sejarah. Situs-situs yang berasal dari masa prasejarah dapat dijumpai di kawasan Rancah dan Tambaksari. Tinggalan arkeologi berupa fosil binatang purba bagian rahang bawah dan taring kuda nil serta beberapa fragmen tulang vertebrata pernah ditemukan di situs Urug Kasang, di tepi Ci Pasang (Agus, 1994). Meskipun fosil manusia secara utuh sampai sekarang belum pernah ditemukan, namun adanya temuan fosil gigi seri homo erectus di Ci Sanca menunjukkan bahwa manusia pernah mendiami kawasan tersebut setidaknya sejak sekitar 800.000 tahun yang lalu (Agus, 2006). Penghunian kawasan ini juga diperkuat dengan adanya temuan alat-alat paleolitik di Ci Pasang berupa kapak perimbas dan kapak penetak (Yondri, 1999). Selain di aliran Ci Pasang, alat batu paleolitik juga pernah ditemukan di aliran Ci Sanca, Desa Kaso (Agus, 1998). Selain fosil binatang dan alat-alat batu, di kawasan Ciamis banyak juga ditemukan situs-situs berlatarkan tradisi megalitik dari masa prasejarah. Beberapa bangunan megalitik yang ada antara lain menhir dan punden berundak (Tim Penelitian, 1993).

Menginjak masa sejarah, wilayah Ciamis seringkali dikaitkan dengan keberadaan kerajaan Galuh dan Sunda. Keberadaan enam prasasti yang terdapat di situs Astana Gede, Kawali menunjukkan bahwa Prabu Raja Wastu merupakan salah satu raja Kerajaan Sunda sewaktu berpusat pemerintahan di Kawali. Berdasarkan prasasti tersebut diketahui bahwa kraton Prabu Raja Wastu bernama Surawisesa. Nama Prabu Raja Wastu juga disebut dalam prasasti Batutulis. Berdasarkan sumber ini diketahui bahwa Prabu Raja Wastu berkuasa pada abad XVI (Nastiti, 1996). Ekskavasi yang pernah dilakukan Balai Arkeologi Bandung di situs Astana Gede menemukan adanya tatanan batu (balai) pada kedalaman sekitar $50 \mathrm{~cm}$ (Prijono, 1994). Tatanan batu tersebut menunjukkan adanya bekas bangunan yang kemungkinan besar merupakan bagian dari kraton Surawisesa. Selain bekas bangunan yang diduga kraton tersebut, di wilayah Ciamis juga ditemukan tinggalan berupa bangunan suci jejak peribadatan dari masa Hindu- Buddha atau masa klasik. Bangunan suci yang ditemukan di wilayah Ciamis adalah Candi Ronggeng.

Situs Candi Ronggeng merupakan salah satu situs dari periode masa klasik di Ciamis yang kondisinya hingga saat ini masih tertimbun tanah. Candi ini merupakan satu-satunya candi yang berada di Kabupaten Ciamis setelah Kabupaten ini mengalami pemekaran menjadi Kabupaten Ciamis, Kota Banjar, dan Kabupaten Pangandaran, sehingga menjadi aset yang sangat berharga bagi daerah. Beberapa penelitian sebelumnya telah 4 (empat) kali dilakukan oleh Pusat Penelitian Arkeologi Nasional, yaitu penelitian tahun 1977 dipimpin oleh Hasan Muarif Ambary, penelitian tahun 1978 dipimpin oleh Endang Sri Hardiati Soekatno serta, penelitian tahun 1983, dan 1984 dipimpin oleh Peter Ferdinandus (Ferdinandus, 1984). Selain penelitian di atas, terdapat pula dua tulisan yang telah membahas tentang Candi Ronggeng, yaitu satu artikel yang berjudul "Melacak Bentuk Bangunan Klasik di Bagian Selatan Jawa Barat (Studi Kasus 
Kecamatan Pamarican, Kalipucang, dan Pangandaran)", ditulis oleh Lutfi Yondri dan Etty S. Saringendyanti, ditulis pada tahun 2000, dan pembahasan singkat mengenai bentuk Candi Ronggeng dalam buku "Arsitektur Bangunan Suci Masa Hindu-Buddha di Jawa Barat" yang diterbitkan oleh Kementerian Kebudayaan dan Pariwisata, Proyek Penelitian dan Pengembangan Arkeologi, pada tahun 2004.

Berdasarkan sumber-sumber tersebut, diketahui bahwa Situs Candi Ronggeng pertama kali ditemukan oleh M. Ojo pada tahun 1958 ketika membuat bata. Temuan singkapan tersebut diduga berupa batu-batu candi dan lingga, kemudian pada tahun 1976 ditemukan kembali Yoni, Nandi, dan batu-batu candi oleh seorang warga yang sedang menggarap sawah. Berdasarkan informasi awal tersebut maka dimulailah serangkaian penelitian yang dilakukan oleh Pusat Penelitian Arkeologi Nasional, Suaka Purbakala, dan Bidang Muskala Jabar, bekerja sama dengan petugas Kecamatan setempat.

Pembukaan sejumlah kotak ekskavasi pada rentang penelitian tersebut menghasilkan singkapan batuan candi yang terbuat dari batu pasir (sandstone) yang berada pada rata-rata kedalaman $140 \mathrm{~cm}$, di bawah lapisan tanah aluvial limbahan banjir Ci Seel. Penelitian terakhir pada tahun 1984 selain melacak struktur batu candi, juga menemukan 2 (dua) Arca Nandi atau yang dikenal sebagai avatara Dewa Siva, terbuat dari batu padas, berada diantara struktur batu-batu candi, dan menghadap ke timur. Arca nandi yang berukuran besar, yaitu panjang $120 \mathrm{~cm}$; lebar $26 \mathrm{~cm}$; dan tinggi 46 pada saat itu disimpan di kantor Kandepdiknas Kecamatan Pamarican, sebelum pada akhirnya disimpan di Museum Karangkamulyan, sedangkan arca nandi yang berukuran lebih kecil, ditimbun kembali (Ferdinandus, 1984). Berdasarkan hasil ekskavasi batubatu yang ditemukan di Candi Ronggeng tidak menunjukkan adanya bagian badan dan atap, sehingga kemungkinan bangunan Candi Ronggeng hanyalah bagian kaki, atau hanya berupa pagar pendek. Sisa struktur batu yang masih dapat ditemukan terdiri dari empat susun balok batu dan di bagian paling bawah berupa boulder batu bulat sebagai pondasi. Dugaan bahwa bentuk Candi Ronggeng hanyalah berupa pagar pendek didasarkan pada adanya temuan batu yang berprofil pada kedua sisinya, yang kemungkinan merupakan bagian paling atas dari struktur dinding. Batu dengan bentuk demikian ini selain yang berbentuk balok panjang, juga berbentuk batu sudut. Beberapa umpak batu juga ditemukan di beberapa kotak ekskavasi. Dengan demikian kemungkinan bentuk Candi Ronggeng adalah di bagian tengah terdapat objek pemujaan berupa nandi dengan atap dari bahan mudah rusak yang ditopang oleh tiang dengan umpak batu bulat. Objek tersebut dikelilingi oleh pagar pendek (Widyastuti et al., 2019; Widyastuti \& Saptono, 2020). Analisis terakhir menyatakan bahwa Candi Ronggeng merupakan Candi Hindu, diduga berukuran 8 x 8 meter, yang berada di lahan rawan banjir sehingga mengancam kekuatan batu-batuan candi. Permasalahan yang diajukan dalam paparan ini adalah langkah apa yang sebaiknya diambil untuk menanggulangi agar candi tidak terendam luapan banjir. Dengan demikian candi ini dapat diselamatkan sebagai salah satu aset daerah Ciamis. 


\section{PEMBAHASAN}

Candi Ronggeng merupakan salah satu dari sedikit situs masa Hindu-Buddha di Jawa Barat yang sudah terungkap. Kelangkaan tinggalan berupa candi di daerah Jawa Barat menjadikan situs Candi Ronggeng penting untuk dilestarikan sebagai bukti keberadaan candi di Jawa Barat. Sebagai salah satu tinggalan masa Hindu-Buddha Candi Ronggeng memiliki nilai penting bagi sejarah budaya dan ilmu pengetahuan. Oleh karena itu keberadaan Candi Ronggeng harus dijaga dari kerusakan yang lebih parah.

Bencana adalah peristiwa atau rangkaian peristiwa yang mengancam dan mengganggu kehidupan dan penghidupan masyarakat, baik yang disebabkan oleh faktor alam/non alam maupun faktor manusia, sehingga mengakibatkan timbulnya korban jiwa manusia, kerusakan lingkungan, kerugian harta benda serta dampak psikologis. Mitigasi bencana merupakan serangkaian upaya untuk mengurangi resiko bencana, baik melalui pembangunan fisik maupun penyadaran dan peningkatan kemampuan menghadapi ancaman bencana (Undang-Undang Republik Indonesia Nomor 24 Tahun 2007 Tentang Penanggulangan Bencana, 2007). Terdapat tiga jenis bencana, yaitu bencana alam, bencana non alam, dan bencana sosial. Untuk menghindari atau mengurangi dampak akibat bencana terhadap cagar budaya diperlukan pengelolaan bencana. Pengelolaan bencana terdiri dari pencegahan/mitigasi, kesiapsiagaan, tanggap darurat, rehabilitasi, dan rekonstruksi pada tahap setelah bencana (Falah, 2019).

Secara administratif situs Candi Ronggeng termasuk wilayah Dusun Kedung Bangkong, Desa Sukajaya, Kecamatan Pamarican. Wilayah Kecamatan Pamarican termasuk di DAS Ci Tanduy. Ci Tanduy merupakan sungai utama di wilayah Ciamis yang mengalir mulai dari Gunung Cakrabuana (hulu) di Kabupaten Tasikmalaya dan bermuara di Sagara Anakan Provinsi Jawa Tengah dengan anak-anak sungainya terdiri dari Ci Muntur, Ci Jolang dan Ci Seel. Di bagian selatan mengalir Ci Medang dengan anak-anak sungainya terdiri dari Ci Kondang, Ci Begal, Ci Paledang, Ci Bungur, Ci Tatah I, Ci Tatah II, Ci Gugur, Ci Haruman, Ci Gembor, Ci Kuya, Ci Jengkol, Ci Magung, dan Ci Condong (Rusyanti \& Saptono, 2017).

Daerah Aliran Sungai (DAS) Ci Tanduy terbagi ke dalam Sub DAS Ci Tanduy Hulu seluas 22.279,38 Ha, Sub DAS Ci Seel seluas 77.421,08 Ha, Sub DAS Ci Muntur seluas 55.163,06 Ha dan Sub DAS Ci Jolang seluas 18.665,99 Ha. DAS Ci Tanduy secara nasional dikategorikan sebagai DAS kritis dengan indikator kekritisan antara lain fluktuasi debit sungai, tingkat erosi dan sedimentasi yang cukup tinggi ( 5 juta ton/tahun terbawa oleh Ci Tanduy), serta produktivitas DAS yang relatif rendah (Rusyanti \& Saptono, 2017).

Berdasarkan letak geografisnya, Kabupaten Ciamis berada pada posisi strategis yang dilalui jalan nasional lintas Jawa Barat - Jawa Tengah dan jalan provinsi lintas Ciamis - Cirebon-Jawa Tengah. Kabupaten Ciamis terletak pada lahan dengan keadaan morfologi datar - bergelombang sampai pegunungan. Kemiringan lereng berkisar antara 0 - > 40\% dengan sebaran 0 - 2\% terdapat di bagian tengah - timur laut ke selatan dan 2 - > 40\% tersebar hampir di seluruh wilayah kecamatan. Jenis tanahnya didominasi oleh 
jenis latosol, podsolik, alluvial dan grumusol. Iklim Kabupaten Ciamis berdasarkan klasifikasi iklim menurut Schmidt-Ferguson, pada umumnya mempunyai tipe iklim C, dengan rata-rata curah hujan sekitar $2.987 \mathrm{~mm} /$ tahun dan suhu rata-rata antara $20^{\circ}$ $30^{\circ} \mathrm{C}$ (BPS Kabupaten Ciamis, 2020).

Secara Geografis Kecamatan Pamarican terletak di antara $07^{\circ} 27^{\prime}$ LS dan $108^{\circ} 31^{\prime}$ BT dengan luas wilayahnya 11.834,38 Ha, dengan ketinggian 34,25 diatas permukaan laut, suhu maksimum $35^{\circ} \mathrm{C}$ dan suhu minimum $25^{\circ} \mathrm{C}$. Batas-batas wilayah Kecamatan Pamarican yaitu Sebelah Utara: Kecamatan Pataruman (Pemkot Banjar), Sebelah Timur: Kecamatan Banjarsari dan Kecamatan Purwadadi, Sebelah Selatan: Kecamatan Banjarsari, dan Sebelah Barat: Kecamatan Langkaplancar dan Kecamatan Cidolog (Rusyanti \& Saptono, 2017).

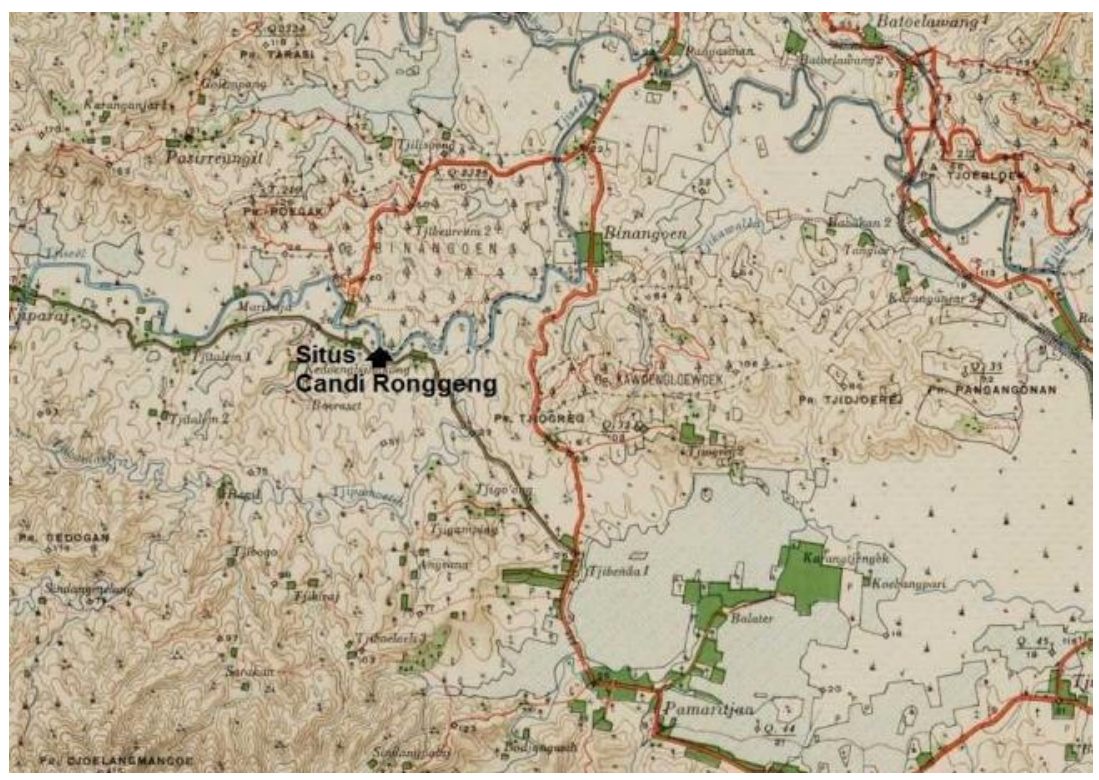

Gambar 1. Topografi kawasan situs Candi Ronggeng (Sumber: Balai Arkeologi Jawa Barat, 2019).

Situs Candi Ronggeng berada di sebelah timur hingga selatan aliran Ci Seel, tepatnya berada pada koordinat $109^{\circ} 29^{\prime}$ BT dan $07^{\circ} 24^{\prime} \mathrm{LS}$, ketinggian $98 \mathrm{~m}$ dpl. Ci Seel mengalir di sebelah utara situs, pola aliran paralel dengan anak-anak sungai. Aliran sungai utama (Ci Seel) berkelok-kelok dari arah barat ke timur. Di sebelah selatan sungai utama terdapat aliran Ci Pamutih yang bersatu dengan Ci Seel di sebelah timur Candi Ronggeng berjarak sekitar 2,3 km. Aliran Ci Seel kemudian berbelok ke utara dan bertemu dengan aliran Ci Kembang selanjutnya berbelok ke arah timur (Gambar 1).

Lahan situs merupakan kebun milik Heri Suheri, 76 tahun. Kondisi lahan pada saat penelitian berlangsung berupa tanah kosong yang sengaja tidak diolah sejak dinyatakan sebagai situs purbakala. Lahan situs berpagar bambu berukuran sekitar $8 \mathrm{x}$ $14 \mathrm{~m}$. Di tengah lahan terdapat pohon bungur (Lagerstroemia L). Pada sisi timur terdapat deretan pohon mahoni (Swietenia macrophylla), pada sisi selatan dan barat terdapat deretan pohon kelapa (Cocos nucifera). Di sebelah selatan lahan situs merupakan jalan kabupaten yang menghubungkan beberapa desa (Gambar 2). 


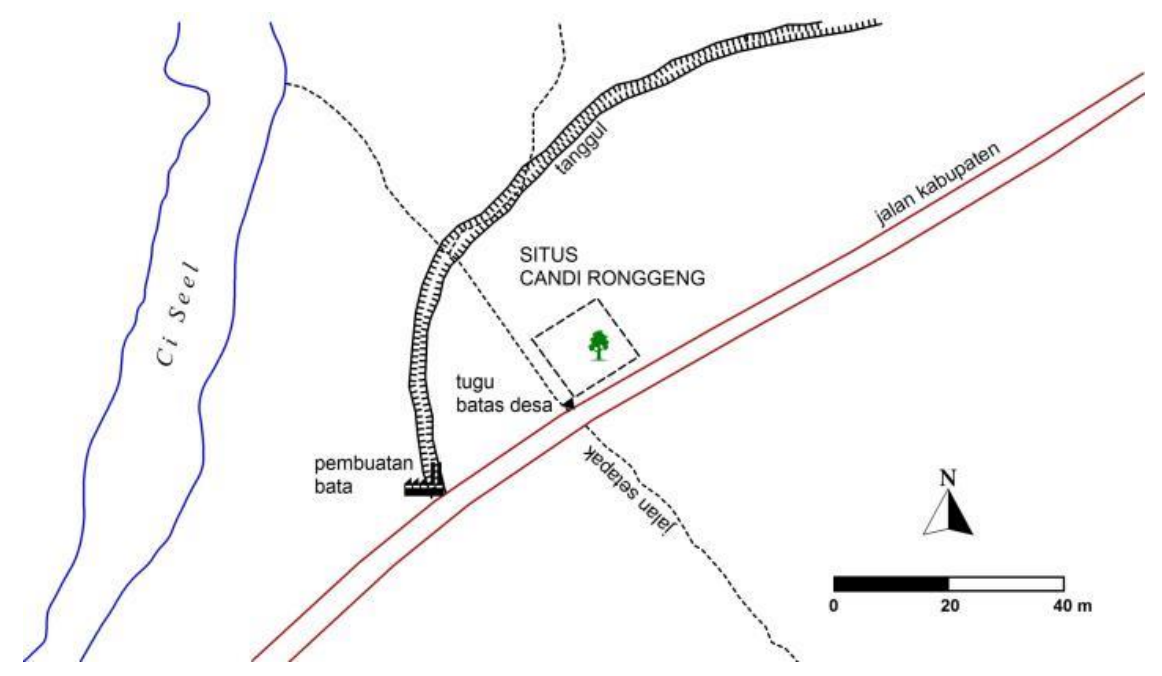

Gambar 2. Situasi situs Candi Ronggeng (Sumber: Balai Arkeologi Bandung, 2017).

Lingkungan sekitar lahan situs pada umumnya berupa kebun tanaman keras seperti pohon rasamala (Altingia excelsa Noronha) dan albasia (Albizia falcataria L.) (Gambar 3). Lahan situs hampir setiap tahun tertimbun oleh lapisan limpah banjir Ci Seel yang meninggalkan lapisan tanah berlempung-pasir berwarna coklat. Lapisan tanah endapan lumpur Ci Seel ini oleh masyarakat dimanfaatkan untuk bahan membuat bata.

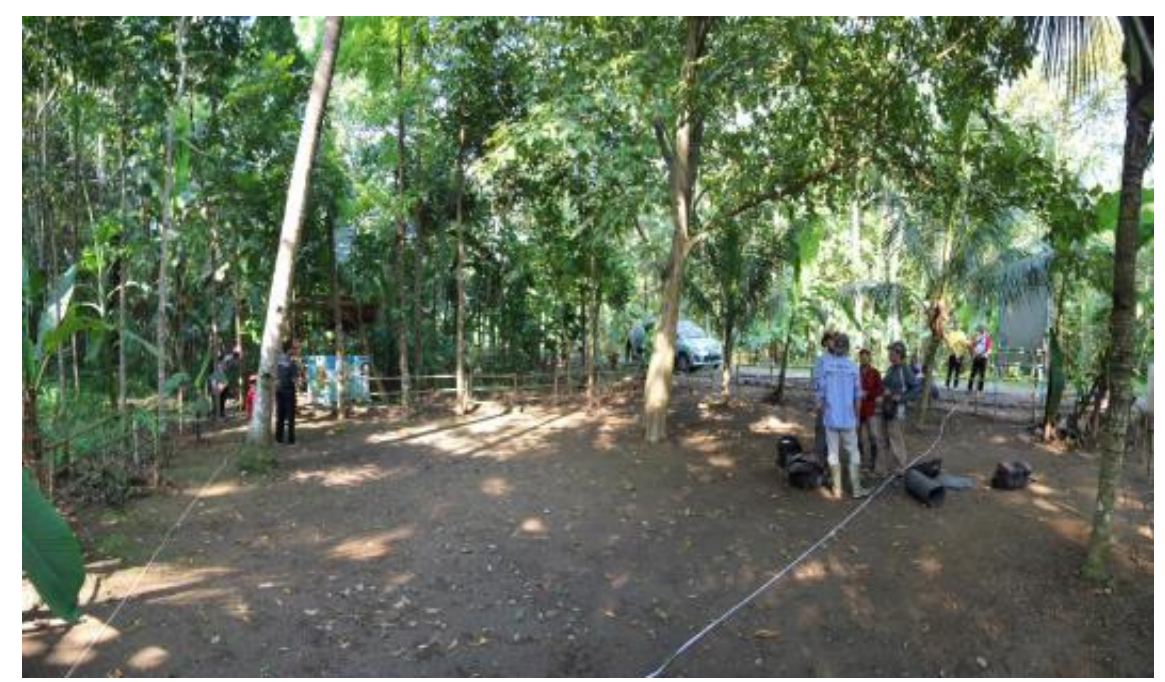

Gambar 3. Kondisi situs Candi Ronggeng (Sumber: Balai Arkeologi Jawa Barat, 2019).

Berdasarkan laporan penggalian pada tahun-tahun sebelumnya, banjir besar pernah terjadi pada tahun 1937, 1943, 1962, dan 1973 dan lebih sering lagi sejak dibangunnya Bendungan Gunung Putri. Jejak endapan banjir tersebut terlihat hingga mencapai ketebalan $140 \mathrm{~cm}$ sampai dengan $200 \mathrm{~cm}$ dari tanah aslinya yang berwarna hitam kecoklatan dan bertekstur pasir-lempungan. 
Banjir adalah suatu kejadian saat air menggenangi daerah yang biasanya tidak digenangi air dalam selang waktu tertentu. Banjir umumnya terjadi pada saat aliran air melebihi volume air yang dapat ditampung dalam sungai, danau, rawa, drainase, maupun saluran air lainnya pada selang waktu tertentu. Faktor utama yang mempengaruhi banjir adalah intensitas curah hujan dan lamanya hujan terjadi. Kondisi topografi, kondisi tanah, serta kondisi tutupan lahan juga memberikan pengaruh yang besar terhadap kejadian banjir (Falah, 2019).

Banjir yang terjadi di situs Candi Ronggeng tercatat sudah beberapa kali terjadi. Lokasi candi yang berdekatan dengan Ci Seel menjadikan situs ini sering terendam limpahan air banjir dari sungai tersebut yang berakibat terjadi endapan lumpur. Kejadian banjir tersebut semakin sering terjadi sejak pembangunan bendungan Gunung Putri di pertemuan Ci Seel dengan Ci Talahab. Usaha untuk menanggulangi genangan banjir telah dibuat tanggul tanah yang berada di antara lahan situs dengan bantaran $\mathrm{Ci}$ Seel. Untuk memaksimalkan peran tanggul, perlu dibuatkan tanggul yang lebih permanen sekaligus digunakan sebagai lokasi pemindahan jalan kabupaten yang terdapat di sebelah selatan situs. Selain itu untuk pengamanan candi, pada waktu dilakukan rekonstruksi dibuatkan talud yang dilengkapi dengan drainase yang dapat dengan cepat mengalirkan air jika terjadi banjir.

\section{SIMPULAN}

Selama ini kesejarahan masa pengaruh Hindu-Buddha di wilayah Jawa Barat masih belum banyak data yang terungkap, dengan adanya Candi Ronggeng ini diharapkan dapat mengisi kekosongan tersebut. Keberadaan Candi Ronggeng yang terancam oleh limpah banjir perlu segera dilakukan penyelamatan agar terhindar dari ancaman kerusakan batuan candi karena rendaman air tanah yang terlalu lama. Alternatif yang diajukan untuk mengatasi rendaman banjir adalah dengan membuat tanggul permanen yang cukup tinggi di tepi Ci Seel, sekaligus sebagai jalur pengganti jalan kabupaten yang semula membelah situs. Selain itu juga perlu dibuatkan talud dan drainase yang memadai pada waktu rekonstruksi bangunan Candi Ronggeng.

\section{UCAPAN TERIMA KASIH}

Ucapan terima kasih penulis sampaikan kepada Nanang Saptono dan Rusyanti yang telah bersedia memberikan masukan-masukan kepada penulis selama persiapan presentasi hingga penyusunan makalah prosiding ini. Ucapan terima kasih juga penulis sampaikan kepada seluruh anggota tim penelitian yang terdiri dari Sukirja, Azhar Rachman, Siswanto, Rizal Yoga Prayoga, dan Oktavian Ardana Putra yang telah membantu dalam pengumpulan data hingga pengerjaan pasca lapangan, terdiri dari penggambaran, analisis, dan yang tidak kalah penting adalah pekerjaan administrasi. Ucapan terima kasih juga penulis sampaikan kepada bapak Heri Suheri sebagai pemilik lahan yang telah mengijinkan tim penelitian untuk melakukan kegiatan ekskavasi. Tak 
lupa pula terima kasih kepada juru pelihara situs Bapak Rahman dan masyarakat dusun Kedungbangkong yang telah membantu sebagai tenaga lokal selama kegiatan ekskavasi.

\section{DAFTAR PUSTAKA}

Agus. (1994). Stratigrafi dan Paleontologi Daerah Urug Kasang, Ciamis, Jawa Barat. Jurnal Balai Arkeologi Bandung, Edisi Perd.

Agus. (1998). Laporan Hasil Penelitian Arkeologi. Penelitian Arkeometri di Daerah Kaso Kabupaten Ciamis (Aspek Stratigrafi \& Paleontologi).

Agus. (2006). Paleontologi Daerah Tambaksari Dan Sekitarnya. In E. S. Hardiati (Ed.), Dimensi Arkeologi Kawasan Ciamis (hal. 1-12). Ikatan Ahli Arkeologi Indonesia.

BPS Kabupaten Ciamis. (2020). Kabupaten Ciamis Dalam Angka 2020. BPS Kabupaten Ciamis.

Falah, W. (2019). Mitigasi Bencana Cagar Budaya Batujaya Kabupaten Karawang. Buletin Kalatirta vol. 7, 22--39.

Ferdinandus, P. (1984). Laporan Penelitian Arkeologi di Kabupaten Ciamis, Jawa Barat tanggal 1 s/d 15 Agustus 1984.

Nastiti, T. S. (1996). Prasasti Kawali. Jurnal Penelitian Balai Arkeologi Bandung, 4.

Prijono, S. (1994). Laporan Penelitian Arkeologi Tentang Identitas Data Untuk Memperoleh Gambaran Transformasi Budaya di Situs Astana Gede.

Rusyanti, \& Saptono, N. (2017). Laporan Penelitian Ekskavasi Situs Candi Ronggeng, Desa Sukajaya, Kecamatan Pamarican, Kabupaten Ciamis, Jawa Barat. Berita Penelitian Arkeologi No. 7.

Tim Penelitian. (1993). Survei Situs-situs Prasejarah: Tinjauan Aspek Keruangan di Kecamatan Cijulang dan Sekitarnya, Kabupaten Ciamis, Jawa Barat" Laporan Penelitian Arkeologi.

Undang-Undang Republik Indonesia Nomor 24 Tahun 2007 Tentang Penanggulangan Bencana, Pub. L. No. 24. (2007).

Widyastuti, E., \& Saptono, N. (2020). Identifikasi Awal Bentuk Bangunan di Situs Candi Ronggeng. Jurnal Panaluntik, 3(1), 45-58. https://doi.org/DOI: https://doi.org/10.24164/pnk.v3i1.42

Widyastuti, E., Saptono, N., Arif, J., Sukirja, Rachman, A., Siswanto, Prayoga, R. Y., \& Putra, O. A. (2019). Bentuk Dan Pola Bangunan Suci Masa Hindu Buddha Di Jawa Barat Bagian Timur.

Yondri, L. (1999). Mungkinkah Manusia Purba Pernah Hidup di Kawasan Jawa Barat? Jurnal Penelitian Balai Arkeologi Bandung, 5.

\section{HASIL DISKUSI}

\section{Tidak ada pertanyaan}

